\title{
Choosing Cleaner and Safer Production Practices through a Multi-criteria Approach
}

\author{
V. Laforest \\ Institut Henri Fayol, École des Mines de Saint-Étienne, Saint-Étienne, 158 cours Fauriel, 42023 Saint- \\ Étienne cedex 2, France, e-mail : laforest@emse.fr
}

G. Raymond,

Institut Henri Fayol, École des Mines de Saint-Étienne, 158 cours Fauriel, 42023 Saint-Étienne cedex

2, France

É. Piatyszek,

Institut Henri Fayol, École des Mines de Saint-Étienne, Saint-Étienne, 158 cours Fauriel, 42023 SaintÉtienne cedex 2, France, e-mail : piatyszek@emse.fr

Corresponding author:

É. Piatyszek

Institut Henri Fayol, École des Mines de Saint-Étienne, Saint-Étienne, 158 cours Fauriel, 42023 Saint-

Étienne cedex 2, France, phone : +33477426 621, fax : +33477426633, e-mail : piatyszek@emse.fr

\begin{abstract}
Through the international (Convention) and European (Industrial Emissions Directive) legislations, industries have to apply preventive measures according to the Best Available Technique (BAT) concept or cleaner production (CP) strategies. Many technical solutions exist to conform, but the major stake is to assess the overall effect or impact of the implementation of a technique on the installation. Several methods have been developed based on LCA or carbon balance methodologies, but they lack the technical, economical and social criteria, which are aspects that should be taken into account when choosing cleaner and safer production practices. This paper presents a decision-making tool based on a multi-criteria analysis approach, likely to encourage manufacturers to implement cleaner and safer production practices in the metal finishing sector. First, a systemic analysis of the industrial facility and its environment is used to identify 15 criteria structured in a hierarchical pattern. These criteria represent the targets which could potentially impacted by a cleaner and safer production practice: for example, water, soil, air, but also the environment of the workstation of an operator, the production processes, etc. Using these 15 criteria, users can then assess up to 86 practices selected in particular in the BREF report dealing with Metal Finishing. Thus, this tool enables the practices the most adapted to a particular company to be chosen not only on financial criteria, but also on a social, environmental and technical view.
\end{abstract}

Key words: Cleaner and safer production, integrated approach, decision-making, multi-criteria analysis, metal finishing 


\section{Introduction}

With a view to restoring the balance of production - consumption / health - environmental, the concept of cleaner production was introduced by the United Nations Environment Programme (UNEP) in 1989 in response to the logic of sustainable production and consumption (UNEP, 2001). This concept became a program of action with two specific objectives:

- Improving eco-efficiency of production in the short and medium term (one might see this as an optimization of production systems using current technical knowledge) and,

- A long-term dematerialization

Globally, the process of adopting cleaner technologies is part of the sustainable development policy defined in Agenda 21, adopted in Rio de Janeiro in 1992, in that it promotes and encourages the adoption of new manufacturing processes that make scale economies of both raw materials and energy, and are cleaner with regard to environmental protection and adjacent populations.

Agenda 21(UNCED, 1992) whose overall goal is to "restructure the decision-making process to fully integrate socioeconomic and environmental issues and get a wider public participation" (art. 8.3), defined in Chapters 30 and 34, on the one hand, the role of industry and trade for sustainable development (i.e. in promoting cleaner production) and, on the other hand, their principles of Action to achieve this.

In addition, Section 34 on the Transfer of environmentally sound technologies, cooperation and capacity building defined as a favoured policy the transfer of "environmentally sound technologies" (awkwardly translated "environmentally sound" or "ecotechnologies "in French). They are linked, by definition, to the principle of promoting the use of prevention technologies and therefore cleaner technologies, but they covered end-of-pipe solutions. Nevertheless, they are considered as a fundamental mechanism of a cleaner and sustainable development.

For more than 15 years, high polluting industries are concerned by a European directive on Integrated Pollution Prevention and Control, also known as the IPPC directive. On November, 24, 2010, the European Parliament adopted the Directive 2010/75/UE relative to the Industrial Emissions (IED). Integrating 6 previous directives, it includes nowadays the IPPC Directive. General principles of the IPPC directive have been retained for the IED, notably concerning the integrated approaches, the flexibility principle, the participative principle and the key principle of the use of the performance of Best Available Techniques (BAT).

Despite the evolution of the European regulation (from IPPC to IED), priority is given to the reduction at the source as much as possible by taking into account the specificity of the organisation and the media in which it is implemented. One theoretical concept assigned to the application of the priority of the IED is the concept of cleaner production (CP). (Laforest, 2008)(Polders, 2012)

Moreover, none methodology is proposed to help decision-makers in the choice procedure of cleaner production strategy. After having presented the context, the existing methodology and the multicriteria theory, this article proposed to present a multicriteria analysis method to support industrialists in their decision procedures.

\section{procedures \\ 2. Best available techniques, cleaner production strategies and their assessment}

The principle of best available techniques (BAT), as defined by the IPPC directive has become a significant issue for the industry to deal with, and the implementation of this Directive actually compels companies to apply BAT. The BAT principle is defined as being "the most effective and advanced stage in the development of activities and their methods of operation which indicate the practical suitability of particular techniques for providing in principle the basis for emission limit 
values designed to prevent and, where that is not practicable, generally to reduce emissions and the impact on the environment as a whole" (directive, 2008).

The terms "best", "available" and "techniques" are detailed as follows:

$>$ 'techniques' shall include both the technology used and the way in which the installation is designed, built, maintained, operated and decommissioned,

$>$ 'available' techniques shall mean those developed on a scale which allows implementation in the relevant industrial sector, under economically and technically viable conditions, taking into consideration the costs and advantages, whether or not the techniques are used or produced inside the Member State in question, as long as they are reasonably accessible to the operator, and

$>$ 'best' shall mean most effective in achieving a high general level of protection of the environment as a whole.

This definition is reinforced in Appendix IV of the IPPC Directive with 12 considerations to be taken into account for the selection of BATs. Unfortunately, this information does not seem to be sufficiently clear to be taken into account for the environmental performance assessment of techniques with regard to BATs.

Otherwise, the cleaner production principle involves the continuous use of industrial processes and products to increase efficiency and to diminish their impact on humans and the environment.

Both BATs and CP represent viable preventive environmental approaches for the reduction of pollution at the source. These two concepts are more or less the same. In application of the principles of cleaner production, the definition of BATs corresponds at first to prevention pollution techniques. Only when reduction at the source is not practicable, curative techniques (i.e. end-of-pipe techniques) can be considered as BATs (Polders, 2012).Then the greatest difference is that an end-of-pipe solution (for instance, a waste water treatment plant) can be a BAT but not a CP strategy. (laforest, 2008)

Therefore, the concept of cleaner production applies to actions which aim at reducing pollution upstream of processes and services with a view to reduce the impact on man and the environment. The ability of cleaner production practices to decrease the pressure exerted on the environment by human activities, improve production processes and generate profit has already been demonstrated (Giannetti, 2008; Kjaerheim, 2003). However, and although clean technologies are really interesting, very few applications exist today, and manufacturers show very little concern for the environment (Laforest, 2008). A recent survey conducted with French managers of companies with less than 250 workers illustrated that even though they feel concerned by environmental protection (82\%), $72 \%$ have not taken any action in this field and do not intend to do so (Gault, 2009). Both ignorance of environmental impact and the fact that impact assessment tools and decision-making tools are not readily available may account for such a disinterest in cleaner production strategies. According to Gault (Gault, 2009), the environmental decision-making stage very often depends on the manager's personal vision (52\% of surveyed managers) (Kabongo, 2004). It is also mostly based on financial criteria.

And yet deciding to implement cleaner production practices covers a number of specific features:

- A multi-criteria approach; cost is not the only decisive criterion. Other criteria such as the impact of the technology on water, the level of maintenance actions, or the working conditions are also essential to control the impacts of the technique used.

- Decisions are made by many actors who may not always agree, like the ordering party, manufacturers, experts, financers, and even customers.

- A large number of cleaner and safer production (CSP) practices do exist, relating to processes, products and how to implement them.

Today, many environmental assessment tools exist whose scope may exceed the physical limits of an industrial facility. For example, the Life Cycle Assessment methodology helps to quantify a set of 
potential environmental impacts all along the life of the system studied (ISO, 2006)(Aissani, 2008)(Styles, 2009)(Valderrama, 2012). Other tools such as carbon balance or ecological footprint propose environmental performances from one single criterion which is the aggregation of a set of indicators. Nevertheless they take into account only environmental impacts even if social and cost criteria are starting to be implemented in some studies. Moreover, these method (LCA, carbon balance, ecological footprint) need a lot of data which are often not available for assessment notably the characterization factors. Then industrial operators have difficulties in assessing their impact as a whole through an integrated approach in terms of management procedures and technologies. Thus, operators need to identify other relevant, coherent, accessible and representative indicators within the general industrial context in order to identify an overall performance level.

Nevertheless, many methodologies have been developed to conform to the IPPC/IE directive (Geldermann, 2004)(Dijkmans, 2000)(Barros, 2007). However each of them is focused on a specific activity because of the specificity of the organization of each production system.

Our contribution to all these existing methodology is first of all, to link, by the decision making tool developed, cleaner production strategy expertise and best available technique reference documents on a specific application and secondly, to take into account as well, environmental, technical, economic and social effects. Moreover, it is intended that this methodology be based on specific, local and real data in order to be as representative as possible of the effect of existing studies on CP strategies.

Environmental assessment results are usually given by environmental impact assessments which illustrate the potential impact of the system under review on the environment. Nevertheless, when implementing a cleaner production strategy, decision makers want to have solid information on the effects on emissions, the operator behaviors, the economic issue and the product quality. This is why the assessment will be more focused on environmental, technical, social and economic aspects than only on environmental impacts.

Literature with reference documents on best available techniques (BREF), national technical documents, scientific articles and others demonstrate that a lot of technical solutions are available to access cleaner production or best available techniques. Considering both the numbers of potential criteria and available techniques, the choice is not trivial. "Humans cannot keep the meanings of more than seven (plus or minus two) alternatives in mind simultaneously. Larger numbers encourage coding habits to form and allow preferences to develop" (Krippendorff, 2004). Resorting to a multi-criteria analysis is therefore essential to facilitate the use of clean production practices within the industrial facility and to provide information used for decision makers.

The purpose of this paper is to present and describe a decision-making tool to select CSP practices using the so-called Electre multi-criteria analysis approach. This paper will first briefly explain the use of Electre I and will subsequently describe the method used to facilitate the selection of CSP practices. Then an example of a metal finishing SME will be given before the conclusions are drawn.

\section{Surface treatment facilities as a key-application}

Surface treatment of metals or plastics aims to change the surface properties of pieces for decoration and/or reflectivity, improve hardness, prevent from corrosion or improve electrical conductivity. Currently, the main areas of application are jewelers, automotive and transportation, packaging and microelectronics.

The market structure in volume is as follows: automotive $22 \%$, construction $9 \%$, food and drink containers $8 \%$, electric industry $7 \%$, steel semi product $7 \%$, electronic industry $7 \%$, industrial equipment $5 \%$, aerospace industry $5 \%$, unspecified $30 \%$ (BREF, 2006).

In Europe, the surface treatment of metals and plastics is carried out in more than 18300 installations, from mainly small or medium enterprises to multinational corporations. 
Our study is focused on the aqueous treatment, which is the most polluting with respect to wastewater. For the surface treatment, a production line is composed of successive tanks filled in with chemical solutions or water, in which the products to treat are plunged. Treatment tanks are separated by rinsing tanks. These two types of tanks can accumulate pollution through the drag process, which produces wastewater. Used process waters are often treated in on-site wastewater treatment plants (end-of-pipe solution). If the treated effluent is conform to the threshold of the regulation (emission limit values), the discharge is then released directly to surface waters, but it can also be discharged to municipal wastewater treatment plants. Although the industry has improved both its practice and infrastructure in many areas, it is still the source of a significant number of environmental impacts. For France, from 1992 to 2002, $1.2 \%$ of all serious industrial water pollution incidents were attributable to this sector, rising to $5 \%$ for 'near misses' (BREF, 2006).

Because of the technical, environmental, social and economical stakes of this activity and its history in the Rhône-Alps region, we have decided to focus our study on it.

\section{Theory: Multi-criteria analysis method}

When dealing with a multi-criteria approach, problems are essential when choosing a method (Saaty, 1984). According to the type method defined by Bernard Roy, they can be choosing ( $\alpha)$, ranking $(\beta)$, or sorting $(\gamma)$ problems (Roy, 1991). In our case, we would like to help industries choose the best way to reduce pollution at the source by using an integrated approach. This situation deals with problem $\alpha$, i.e. one practice will be chosen among a number of innovating practices.

Three kinds of multicriteria analysis exist. The American one widely used in the United States seeks to maximize a utility function linked to each potential action. The "French approach" (developed exclusively by French researchers) consists in the acceptance of the incomparability and intransitivity of criteria. And finally, the local iterative aggregation approach proceeds by an iterative method to approximate the best solution among a large number of potential actions. Table 1 gathers several methods and their advantages and drawbacks: WSM, which seems to simplify too much, is not retained. The same happens to the MAUT and UTA methods, which are based on unclear and non realistic utility concepts. Also, local iterative aggregation methods are excluded because of the necessity to be on constant relation with the decision-maker for each iteration. Electre Is results from Electre I and Iv by improving them, even if this innovation rigidifies the method. Thus, Electre I seems to be the most relevant method for our objective to choose the best cleaner production strategy.

Table 1: studied methods of multicriteria analysis and their advantages and drawbacks

\begin{tabular}{|c|c|c|c|c|}
\hline Method & Type & Description & Advantages & Drawbacks \\
\hline WSM & \multirow{4}{*}{ 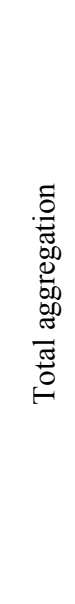 } & - Weighting sums & - Simple use & $\begin{array}{l}\text { - Arbitrary assignment of weights } \\
\text { - Compensation between criteria }\end{array}$ \\
\hline MAUT & & $\begin{array}{l}\text { - Explicit utility } \\
\text { function to obtain an } \\
\text { ranking of option }\end{array}$ & $\begin{array}{l}\text { - Avoid arbitrary assignment } \\
\text { of weights }\end{array}$ & $\begin{array}{l}\text { - Utility concept unclear } \\
\text { - Rationality of the decision- } \\
\text { maker } \\
\text { - Lack of realism }\end{array}$ \\
\hline UTA & & $\begin{array}{l}\text {-Explicit utility function } \\
\text { to obtain an ranking of } \\
\text { option }\end{array}$ & $\begin{array}{l}\text {-More realistic than MAUT } \\
\text {-Admits the revision of the } \\
\text { coherence }\end{array}$ & - Utility concept unclear \\
\hline AHP & & $\begin{array}{l}\text {-Hierarchical method of } \\
\text { binary comparison of } \\
\text { elements to establish } \\
\text { the priority between } \\
\text { options }\end{array}$ & $\begin{array}{l}\text { - Intuitive and attractive } \\
\text { method which admits } \\
\text { quantitative and qualitative } \\
\text { criteria and relative or } \\
\text { absolute values. } \\
\text { - Consistency check }\end{array}$ & $\begin{array}{l}\text { - Subjectivity of the analysis } \\
\text { - A maximum number of criteria } \\
\text { to compare and decision-makers } \\
\text { - Ranking reverse }\end{array}$ \\
\hline
\end{tabular}




\begin{tabular}{|c|c|c|c|c|}
\hline ELECTRE I & \multirow{3}{*}{  } & $\begin{array}{l}\text { - Based on the upgrade } \\
\text { of actions from each } \\
\text { other based on ratings } \\
\text { criteria. }\end{array}$ & $\begin{array}{l}\text { - Realistic method } \\
\text { - Clear establishment of links } \\
\text { between actions } \\
\text { - Reduce cycle problems }\end{array}$ & $\begin{array}{l}\text { - Heaviness of calculation } \\
\text { - Lack of result clarity } \\
\text { - Use of marks }\end{array}$ \\
\hline ELECTRE Iv & & $\begin{array}{l}\text { - Based on the upgrade } \\
\text { of actions from each } \\
\text { other based on } \\
\text { performance criteria. }\end{array}$ & $\begin{array}{l}\text { - Realistic method } \\
\text { - Clear establishment of links } \\
\text { between actions } \\
\text { - Data mastering }\end{array}$ & $\begin{array}{l}\text { - Heaviness of calculation } \\
\text { - Lack of result clarity } \\
\text { - Less flexible than Electre I } \\
\text { because of the use of veto } \\
\text { thresholds }\end{array}$ \\
\hline ELECTRE Is & & $\begin{array}{l}\text { - Based on the upgrade } \\
\text { of actions from each } \\
\text { other based on } \\
\text { performance criteria. }\end{array}$ & $\begin{array}{l}\text { - Clear establishment of links } \\
\text { between actions } \\
\text { - Data mastering } \\
\text { - Correction of the brutality } \\
\text { of the concordance with } \\
\text { indifference and preference } \\
\text { thresholds }\end{array}$ & $\begin{array}{l}\text { - Heaviness of calculation } \\
\text { - Lack of result clarity } \\
\text { - Less flexible than Electre Iv } \\
\text { because of the use of indifference } \\
\text { and preference thresholds }\end{array}$ \\
\hline STEM & 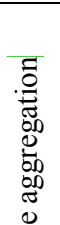 & $\begin{array}{l}\text { - Determination of } \\
\text { effective action by } \\
\text { minimizing the } \\
\text { weighted distance } \\
\text { augmented of } \\
\text { Tchebycheff }\end{array}$ & - Simple calculation steps & $\begin{array}{l}\text { - Modelling rigidity } \\
\text { - Permanent dialogue with } \\
\text { decision-makers }\end{array}$ \\
\hline VINCKE & 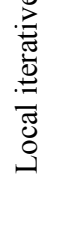 & $\begin{array}{l}\text { - Determination of } \\
\text { effective action by } \\
\text { minimizing the } \\
\text { weighted distance } \\
\text { augmented of } \\
\text { Tchebycheff }\end{array}$ & $\begin{array}{l}\text { - Simple calculation steps } \\
\text { - More flexible than STEM }\end{array}$ & $\begin{array}{l}\text { - Permanent dialogue with } \\
\text { decision-makers }\end{array}$ \\
\hline
\end{tabular}

Electre I is a simple, intuitive method that comes into this assignment problem. It helps compare possible solutions to a given decision-making issue containing several criteria (Bouyssou., 1992) and is made up of five main stages (shown on Fig.1).

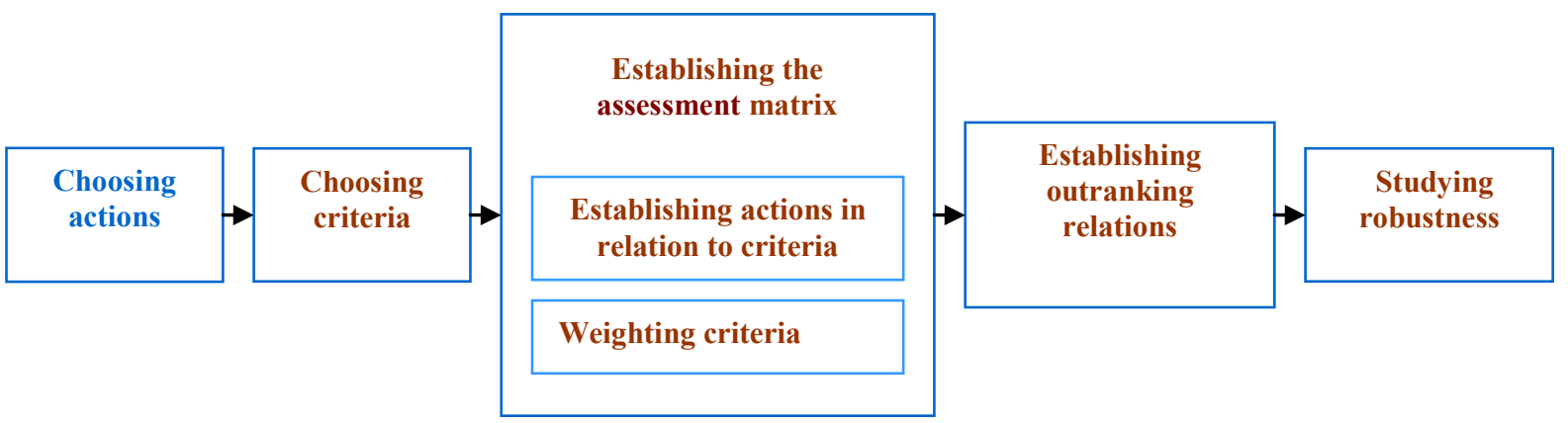

Figure 1: The five steps to carry out Electre I

\subsection{Choosing Actions}

The set of potential actions (named A) that may be selected by the decision-maker is first defined. A potential action $\left(\mathrm{a}_{\mathrm{i}}\right)$ is a real or fictive action that is temporarily deemed realistic by at least one decision-maker (Maystre et al.1994).

\subsection{Choosing Criteria}

According to Roy's definition (Roy, 1991), criterion $\mathrm{g}_{\mathrm{j}}$ is an attribute of action $\mathrm{a}_{\mathrm{i}}$; therefore, the consequences of the actions must be contemplated when choosing the criteria.

All of the criteria chosen represent family $F$ which contains $n$ criteria $\left\{g_{1}, g_{2}, \ldots, g_{n}\right\}$. 
However a number of properties must be observed when choosing family F:

- Exhaustiveness: all of the problem aspects must be represented

- Cohesiveness: when two actions show similar performance for all criteria but one $g_{j}$, the action showing the best $g_{j}$ will be preferred by the decision-makers

- Non-redundancy: a point of view must not appear several times in the same criteria family retained (Maystre et al., 1994). 


\subsection{Establishing the Assessment Matrix}

The judgment matrix must be set up with the greatest care, as it is a crucial aspect of the multi-criteria analysis. This matrix forms a crosstab in which A's actions are in rows and F's criteria are in columns. Assessment, named $g_{j}\left(a_{i}\right)$ is at the crossing of row $i$ and column $j$. This matrix is used to assess data in the most objective way possible. Since the Electre I method cannot be used to work with true values, they are turned into marks on an ordinal or a cardinal scale that applies to individual criteria (Maystre, 1994). The classes represented on the ordinal scale can only be replaced by relations of the "smaller than", "greater than", "equal to" type (e.g. very good, good, neutral, acceptable, bad). In the cardinal scale the values can be linked by the four basic arithmetic operations $(+, \mathrm{x}, \div,-)$.

After assessing the actions the various criteria need to be weighted by assigning weight $p_{j}$ : the greater the weight, the more important the criterion. Assessment $\mathbf{g}_{\mathbf{j}}\left(\mathbf{a}_{\mathrm{i}}\right)$ is then transposed to a numerical scale, the length of which adapts to the weight of each criterion (Schärlig, 1985). The judgment matrix features the quantitative assessment for each criterion.

\subsection{Establishing Outranking Relations}

The Electre methods are based on Condorcet's principle which establishes that " an action will outrank another action if it is at least as good as the other action in relation to a majority of criteria, without being clearly worse than this other action in relation to the other criteria" (Schärlig, 1985). All actions are compared with one another by Electre I, using outranking relations. Sometimes, Electre can not compared actions (they are not outranked by other actions, but outrank no other actions). As explain in part 3.4, Electre is based on outranking relations using concordance and discordance index. These two indexes are compared to two thresholds (concordance threshold and discordance threshold). One can change the value of these two thresholds to limit this problem.

Two important aspects must be defined. First, the concordance, which refers to a measurement of the agreement between two variables and the discordance, which refers to the mutual position of two phenomena whose changes are in opposite directions.

First, the method makes the following calculations:

- Concordance index $c(a, b)$ ( $\mathrm{a}$ and $\mathrm{b}$ are the two actions to compare) such that

$c(a, b)=\frac{1}{P} \sum_{j: g_{j}(a) \geq g_{j}(b)} p_{j}$ where $P=\sum_{j=1}^{n} p_{j}$

- Discordance index $d(a, b)$ such that

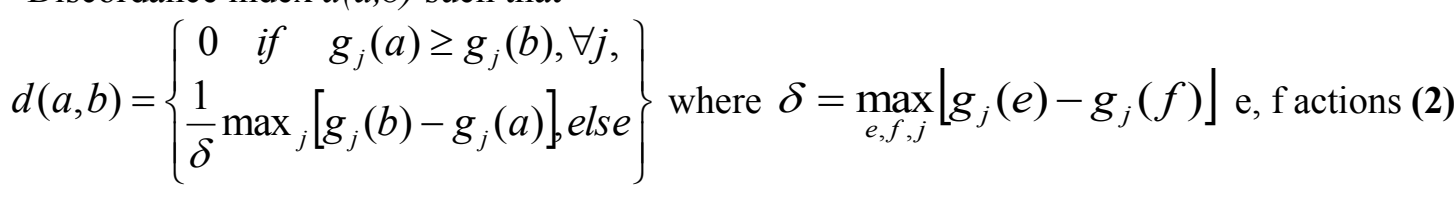

Comparing the indices to the concordance threshold $\hat{c}$ (rather big) and a discordance threshold $\hat{d}$ (rather small) helps express the smallest concordance level required and the biggest acceptable discordance level. The outranking relation is as follows:

aSb if, and only if $\left\{\begin{array}{l}c(a, b) \geq \hat{c} \\ d(a, b) \leq \hat{d}\end{array}\right.$ 
The result of outranking (the so-called Electre core) is then made up of outranking actions that are not outranked by any other core action.

\subsection{Studying Robustness}

Finally, a sensitivity analysis is performed in order to study the stability of the results obtained. To this end, each parameter is varied to determine in which range of values the result (e.g. Electre core) remains unchanged. The method consists in repeating the original multi-criteria analysis and varying first individually, then collectively the values assigned initially to the various parameters (weight, scale, indices, etc.). The sensitivity analysis will be the base of the robustness analysis, which in turn will help determine the result's validity range and set up an operating recommendation. If no result alteration is observed when varying the parameters around their initial value, then the results are not altered; the recommendation is said to be robust (Främling, 1996; Maystre et al., 1994).

\section{Practices \\ 4. Calculation: Using Electre I to Work out a Decision-making Tool for Choosing CSP}

This section presents the development of the Decision-making Tool for choosing CSP for metal finishing facilities. As already explained in the previous section, the Electre I method consists of 5 different stages, whose detailed application is described below. These stages correspond to the steps of the methodology leading to the decision-making tool.

\subsection{Choosing Potential Actions}

Many cleaner and safer production practices are available today. Each practice can be considered as a potential action. The most common cleaner practices set up in the metal finishing sector have been listed, mostly in the BREF STM (Surface Treatment of Metals and Plastics), a European technical guidance report dealing with Metal Finishing. Moreover, the production practices can be sorted according to 8 cleaner production strategies (Good practices, Better process control, Replacing incoming matters, Modification of processes, In-situ regeneration, By-product regeneration, Changing technical methods, Modification of product) (Lanteigne, 2007). Both strategies and examples of application in the metal finishing sector are shown in Table 2.

\begin{tabular}{lll}
\hline Strategy & Definition & Example \\
\hline Good & Adopting management and operation measures & $\bullet$ Systematic closing of taps \\
practices & intended to prevent leakage, accidental spill of & - Control and optimisation of \\
& contaminants; enforce existing operation & storage of chemicals \\
& instructions, etc. & $\bullet$ Covering unused baths
\end{tabular}

\begin{tabular}{lll}
\hline Better & Altering operation procedures, equipment & \\
process & instructions for use, reading methods to improve & - Optimising rinsing parameters \\
control & process efficiency and reduce both waste and & to improve rinsing parameter \\
& emissions. & $\begin{array}{l}\text { efficiency } \\
\end{array}$ \\
& & $\begin{array}{l}\text { Setting up static mounting for } \\
\text { hand-operated lines }\end{array}$ \\
& & - Maintenance of rectifiers
\end{tabular}

Replacing Using less polluting, less rare, less energyincoming consuming matters, use of materials with a matters longer service life for manufacturing processes
- Replacing cleaning with chlorinated solvents by waterbased cleaning solvents 


\begin{tabular}{lll}
\hline of processes & & spray rinsing \\
\hline $\begin{array}{l}\text { In-situ } \\
\text { regeneration }\end{array}$ & $\begin{array}{l}\text { Re-using flows in the same process or in } \\
\text { another process }\end{array}$ & $\begin{array}{l}\text { ・ Using ion-exchanging resins to } \\
\text { re-use process } \text { water }\end{array}$ \\
\hline $\begin{array}{l}\text { By-product } \\
\text { regeneration }\end{array}$ & $\begin{array}{l}\text { Turning waste into by-products that can be sold } \\
\text { as raw materials }\end{array}$ & $\begin{array}{l}\text { • Using an electrolysis method to } \\
\text { recover noble metals }\end{array}$ \\
\hline $\begin{array}{l}\text { Changing } \\
\text { technical } \\
\text { methods }\end{array}$ & $\begin{array}{l}\text { Replacing technical methods, operation } \\
\text { sequence, synthesis methods to reduce } \\
\text { emissions and waste during the production stage }\end{array}$ & $\begin{array}{l}\text { Replacing electroplating by } \\
\text { chemical deposit in vapour phase }\end{array}$ \\
\hline $\begin{array}{l}\text { Modification } \\
\text { of product }\end{array}$ & $\begin{array}{l}\text { Altering product characteristics to make product } \\
\text { more functional, improve product lifetime, and } \\
\text { reduce product impact on environment. }\end{array}$ & $\begin{array}{l}\text { No examples available in the } \\
\text { metal finishing sector. }\end{array}$ \\
\hline
\end{tabular}

Table 2: Cleaner production strategies and examples given in the metal finishing sector (laforest, 1998)

The practices were selected based on their recursion in industrial applications, as well as on the availability of the data used to assess them. Thus, 86 practices were selected. The "product modification" strategy was not taken into account as it is rarely implemented in the metal finishing sector. Also, this strategy depends on the type of product and company, which limits the adaptability of the method. The same is true for the "in-situ regeneration" and "by-product regeneration" strategies that were combined into a single "regeneration" strategy, for very few CSP practices have been listed in terms of by-product re-use.

\subsection{Choosing Criteria}

As said in paragraph 2.2, the consequences of the actions taken need to be considered when choosing the criteria (Roy, 1991). A systemic analysis served as a basis for drawing up the criteria. The purpose of the systemic analysis was first to analyse the industrial facility and its environment, and then to identify the targets, which would potentially be impacted by a CSP practice (Raymond, 2008).

The systemic modelling of the enterprise and its environment has highlighted the sub-systems susceptible to be impacted by VSP practices. To determine the impact level, it is necessary to measure them with criteria. The latest must reflect the completeness of the potential impacts. Identification of CSP criteria is based notably on the use of the MOSAR method used in risk sciences for hazardous situation. Then, criteria identified must be completed with these considered for normal operating.

Then a functional analysis has been carrie out. SADT method has been used because it is founded on a systemic approach and use flux diagrams. This representation has allowed to put forward the complexity of the system studied and to complete the list of criteria.

Then, to develop the sub-system called "strategy", authors have used the Balanced Score Card method proposed by Kaplan and Norton (Kaplan et al., 1996).

Then fifteen criteria were deemed relevant for choosing cleaner and safer production practices. The 15 criteria were structured in a hierarchical pattern, as shown below (Fig.2) (Raymond, 2008).

Figure 2: Hierarchical structure of the criteria 
Figure 2: Hierarchical structure of the criteria

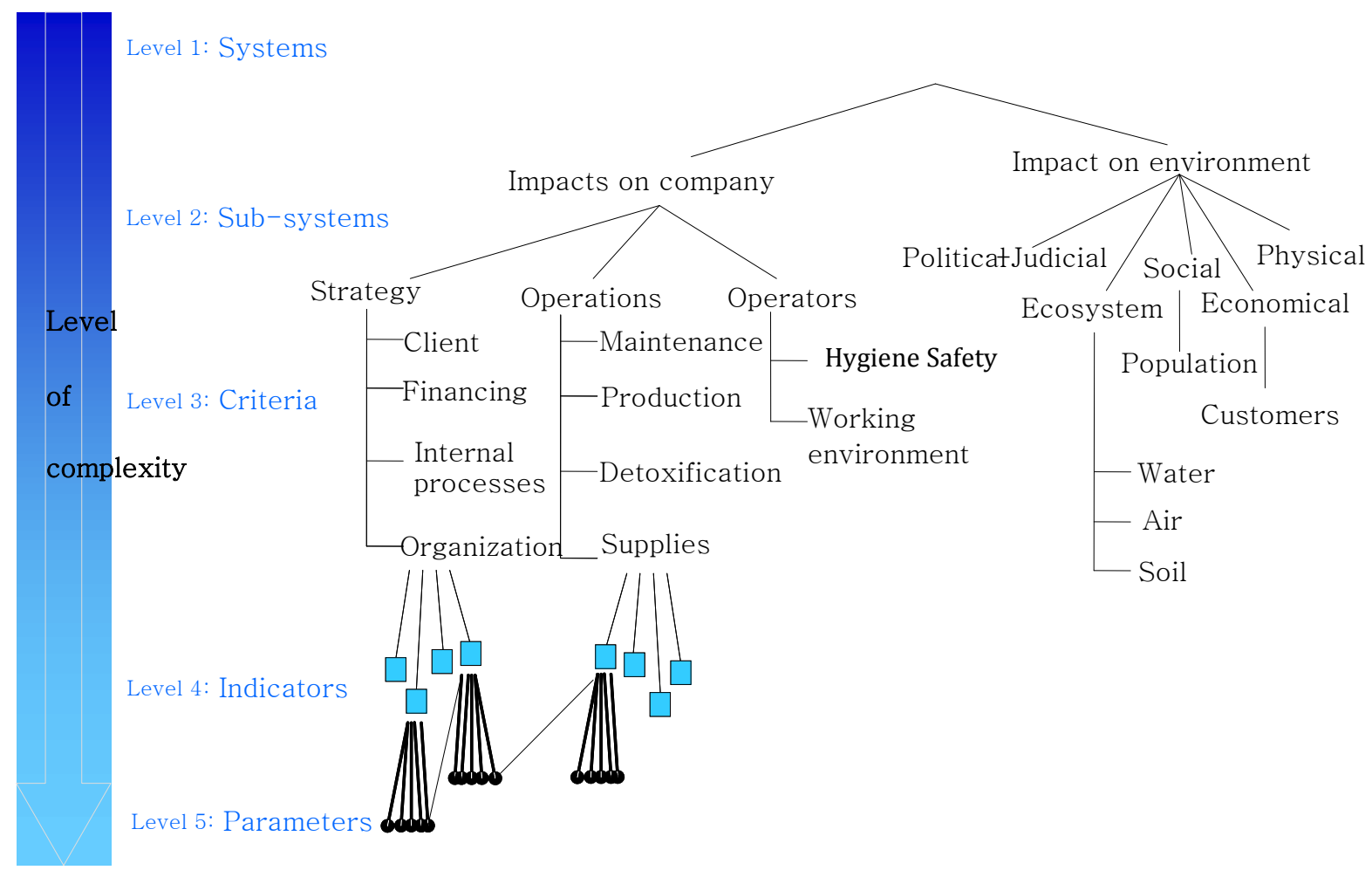

Of course these criteria are not equivalent and therefore have to be weighted. According to Styles and Ahlroth, several weighting methods can be applied. We have chosen the panel weighting method which allows to gathered stakeholder opinion and expertise to weight criteria (Styles, 2009)(Ahlroth, 2011). To this end, a questionnaire (appendix 1) was sent to about twenty experts (metal finishing manufacturers, DRIRE inspectors (Regional Directorate for Industry, Research and Environment), researchers, etc.). The questionnaire was exploited using Saaty's analytic hierarchic process (Saaty, 1984). Each criterion was assigned a weight that was representative of the advice of the professionals and experts of the industrial sector. The various CSP criteria and their respective initials weights assigned through expert's analysis are shown in Table 3.

Table 3: Cleaner and safer production criteria

\begin{tabular}{l|llc}
\hline N\# & \multicolumn{1}{|c}{ Criteria } & \multicolumn{1}{c}{ Definition } & Weight \\
\hline 1 & Water & $\begin{array}{l}\text { "Water" environment as both resource and receiving } \\
\text { medium. }\end{array}$ & 0.65 \\
\hline 2 & Air & "Air" receiving medium & 0.13 \\
\hline 3 & Soil & "Soil" receiving medium & 0.21 \\
\hline 4 & Population & $\begin{array}{l}\text { The social environment in which the company is } \\
\text { working: individuals (side residents) or groups of } \\
\text { individuals (conservationists, nearby companies) } \\
\text { (Dassens, 2007) }\end{array}$ & 0.27 \\
\hline
\end{tabular}




\begin{tabular}{l|lll}
\hline 5 & Customer & Observing customer's specifications. & 0.22 \\
\hline 6 & Hygiene \& safety & Involving risks for operators & 0.37 \\
\hline 7 & Working conditions & Environment of operator's workstation & 0.63 \\
\hline 8 & Maintenance & $\begin{array}{l}\text { Maintenance operations of production equipment as } \\
\text { well as the industrial facility as a whole }\end{array}$ & 0.19 \\
\hline 9 & Production & Production processes. & 0.37 \\
\hline 10 & Detoxification & Treatment of water and gas effluents and waste & 0.24 \\
\hline 11 & Supplies & Supply operations & 0.2 \\
\hline 12 & Financing & Financing resources & 0.22 \\
\hline 13 & Customer strategy & Capacity of company to gain customer loyalty & 0.43 \\
\hline 14 & Internal processes & Performance of company's processes & 0.16 \\
\hline 15 & Organisation & Organisation performances. & 0.19 \\
\hline
\end{tabular}

\subsection{Establishing the Assessment Matrix}

Because it is not possible to quantitatively evaluate the whole impact criterion due to a lack of available and free data, we propose a complete qualitative assessment.

The 86 CSP practices retained in relation to the 15 criteria were assessed in three steps. The first step consisted in assessing the practices in terms of quality; the second step turned the qualitative assessments into quantitative assessments. The third step was used for evaluating the assessmentrelated uncertainties.

\section{$\checkmark$ Qualitative Assessment}

The qualitative assessment identifies the potential impacts (both positive and negative) of each one of the practices towards the 15 criteria retained. Impact identification rests upon a bibliographic study of the techniques listed in the Metal finishing BREF report. The data were completed by in-situ case studies and a report of experts. An extract of the qualitative assessment matrix is shown below.

Table 4: Extract of CSP practices - Qualitative assessments

\begin{tabular}{|c|c|c|c|c|c|c|c|}
\hline \multirow[t]{2}{*}{ Practices } & \multirow[t]{2}{*}{ Description } & \multicolumn{6}{|c|}{ Criteria } \\
\hline & & Water & Air & \begin{tabular}{|l|} 
Soil \\
\end{tabular} & Population & Customer & $\begin{array}{l}\text { Hygiene \& } \\
\text { safety }\end{array}$ \\
\hline $\begin{array}{c}\text { Replacement } \\
\text { of chromium } \\
\text { (VI) } \\
\text { passivation } \\
\text { layers by } \\
\text { chromium } \\
\text { (III) } \\
\text { conversion } \\
\text { coatings } \\
\left(\mathrm{Cr}_{2} \mathrm{O}_{4}{ }^{2-}\right)\end{array}$ & $\begin{array}{l}\text { Chromium } \\
\text { (VI) } \\
\text { formulation } \\
\text { replaced by } \\
\text { chromium } \\
\text { (III) } \\
\text { formulation. } \\
\text { Replacement } \\
\text { of chromium } \\
\text { (VI) is } \\
\text { recommended } \\
\text { by regulations }\end{array}$ & $\begin{array}{l}\text { Reduction of } \\
\text { toxicity on } \\
\text { environment }\end{array}$ & $\begin{array}{l}\text { Reduction of } \\
\text { air pollution } \\
\text { treatment } \\
\text { requirements, } \\
\text { decreasing of } \\
\text { chromic acid } \\
\text { in } \\
\text { workshop's } \\
\text { ambient air } \\
\text { and outdoor. }\end{array}$ & $\begin{array}{l}\text { Reduction of } \\
\text { soil } \\
\text { contamination } \\
\text { risks by Cr } \\
\text { (VI) }\end{array}$ & $\begin{array}{c}\text { Reduction } \\
\text { toxicity on } \\
\text { environment }\end{array}$ & $\begin{array}{l}\text { Protection } \\
\text { against } \\
\text { similar } \\
\text { corrosion; } \\
\text { greenish } \\
\text { colour } \\
\text { replacing } \\
\text { unpleasant } \\
\text { yellow }\end{array}$ & $\begin{array}{l}\text { Reduction of } \\
\text { toxicity on } \\
\text { work place; } \\
\text { less chromic } \\
\text { acid in } \\
\text { workshop's } \\
\text { ambient air; } \\
\text { very good }\end{array}$ \\
\hline
\end{tabular}




\begin{tabular}{|c|c|c|c|c|c|c|c|}
\hline $\begin{array}{l}\text { Replacement } \\
\text { of chlorinated } \\
\text { solvent } \\
\text { cleaning by } \\
\text { water-based } \\
\text { cleaning } \\
\text { solvents or } \\
\text { petroleum } \\
\text { solvents }\end{array}$ & $\begin{array}{l}\text { Acids and } \\
\text { bases replace } \\
\text { solvents } \\
\text { harmful for } \\
\text { humans and } \\
\text { environment }\end{array}$ & $\begin{array}{l}\text { Petroleum } \\
\text { solvents are } \\
\text { less harmful } \\
\text { for } \\
\text { environment, } \\
\text { terpenes are } \\
\text { biodegradable }\end{array}$ & $\begin{array}{l}\text { Less VOC } \\
\text { emissions }\end{array}$ & $\begin{array}{l}\text { Larger use of } \\
\text { soil }\end{array}$ & $\begin{array}{l}\text { Positive } \\
\text { image when } \\
\text { chlorinated } \\
\text { solvents are } \\
\text { not used }\end{array}$ & $\begin{array}{l}\text { Weakened } \\
\text { cleaning } \\
\text { quality }\end{array}$ & $\begin{array}{l}\text { Alkaline lyes } \\
\text { less harmful } \\
\text { for man than } \\
\text { chlorinated } \\
\text { solutions, low } \\
\text { flash point of } \\
\text { terpenes }\end{array}$ \\
\hline Electrolysis & $\begin{array}{l}\text { Enables i) } \\
\text { reduction at } \\
\text { cathode (of } \\
\text { cation } \\
\text { deposit) and } \\
\text { ii) oxidation } \\
\text { at anode } \\
\text { (destruction } \\
\text { of anions) of } \\
\text { electrolyte's } \\
\text { chemical } \\
\text { compounds }\end{array}$ & $\begin{array}{l}\text { Savings on } \\
\text { water } \\
\text { consumption; } \\
\text { effluents } \\
\text { complying to } \\
\text { thresholds, } \\
\text { Destruction of } \\
\text { cyanide } \\
\text { through } \\
\text { electrolytic } \\
\text { oxidation }\end{array}$ & $\begin{array}{l}\text { Caution: } \\
\text { production of } \\
\text { dihydrogen }\end{array}$ & - & $\begin{array}{l}\text { Possible } \\
\text { production } \\
\text { of explosive } \\
\text { mixtures }\left(\mathrm{H}_{2}\right. \\
\left.\text { and } \mathrm{O}_{2}\right), \\
\text { Destruction } \\
\text { of cyanide }\end{array}$ & $\begin{array}{l}\text { Recovery } \\
\text { of } \\
\text { cadmium } \\
\text { or noble } \\
\text { metals; } \\
\text { Quality }\end{array}$ & $\begin{array}{l}\text { Possible } \\
\text { production of } \\
\text { explosive } \\
\text { mixtures }\left(\mathrm{H}_{2}\right. \\
\left.\text { and } \mathrm{O}_{2}\right) \text {, } \\
\text { Destruction of } \\
\text { cyanide }\end{array}$ \\
\hline $\begin{array}{l}\text { Covering of } \\
\text { unused baths } \\
\text { or use of } \\
\text { floating balls }\end{array}$ & $\begin{array}{l}\text { Limits heat } \\
\text { losses due to } \\
\text { evaporation, } \\
\text { thus reducing } \\
\text { energy } \\
\text { consumption } \\
\text { needed for } \\
\text { keeping bath } \\
\text { at proper } \\
\text { temperature }\end{array}$ & $\begin{array}{l}\text { Reduces } \\
\text { consumption of } \\
\text { water needed } \\
\text { for readjusting } \\
\text { bath level }\end{array}$ & $\begin{array}{l}\text { Reduces } \\
\text { losses due to } \\
\text { evaporation } \\
\text { and short gas } \\
\text { emissions }\end{array}$ & $\begin{array}{l}\text { Reduces risk } \\
\text { of fortuitous } \\
\text { pollution of } \\
\text { soil }\end{array}$ & $\begin{array}{l}\text { Reduces } \\
\text { risks of } \\
\text { harmful gas } \\
\text { emissions }\end{array}$ & $\begin{array}{l}\text { Has a } \\
\text { positive } \\
\text { influence } \\
\text { of part } \\
\text { quality }\end{array}$ & $\begin{array}{l}\text { Reduces } \\
\text { toxicity of } \\
\text { work place } \\
\text { environment, } \\
\text { global } \\
\text { decrease of } \\
\text { risks }\end{array}$ \\
\hline $\begin{array}{l}\text { Stirring of } \\
\text { process } \\
\text { solution with } \\
\text { air }\end{array}$ & $\begin{array}{l}\text { Bath storing } \\
\text { is often } \\
\text { necessary. } \\
\text { Can be } \\
\text { performed } \\
\text { using } \\
\text { compressed } \\
\text { air }\end{array}$ & $\begin{array}{l}\text { Necessary } \\
\text { topping up of } \\
\text { baths increases } \\
\text { water } \\
\text { consumption }\end{array}$ & $\begin{array}{l}\text { Worsening of } \\
\text { risk of air } \\
\text { jets, mist and } \\
\text { vapours of } \\
\text { floating } \\
\text { particles }\end{array}$ & $\begin{array}{l}\text { Worsening } \\
\text { risk of } \\
\text { fortuitous } \\
\text { pollution of } \\
\text { soil }\end{array}$ & $\begin{array}{l}\text { Noise } \\
\text { pollution } \\
\text { due to air } \\
\text { compressors }\end{array}$ & $\begin{array}{l}\text { Reduces } \\
\text { corrosion, } \\
\text { provides } \\
\text { higher } \\
\text { quality and } \\
\text { better } \\
\text { distribution } \\
\text { of deposits }\end{array}$ & $\begin{array}{l}\text { Worsening of } \\
\text { risk of air jets, } \\
\text { mist and } \\
\text { vapours of } \\
\text { floating } \\
\text { particles }\end{array}$ \\
\hline
\end{tabular}

\section{$\checkmark$ Quantitative Assessment}

Quantitative assessments (marks or values) are required by the Electre I method to provide outranking relations. Qualitative data must therefore be turned into marks as objectively as possible. Different problems came out in the process:

- The data available was not always quantifiable. For example, for "bath covering - water" (Table 4), the qualitative assessment read as follows: "Reduces consumption of water needed for readjusting bath level". However, water reduction could not be quantified; a situation which is encountered in a large number of practices.

- No reference practice existed to choose one practice against another practice.

- Some criteria were not documented; either the practice did not have any impact on the criterion (e.g. the "electrolysis" practice - Soil criterion, Table 3), or the practice had an indirect impact (e.g. workshop toxicity was decreased by the "bath covering" practice, and working conditions of the company's workers were improved. This in turn may lead to improving company's productivity). Here, not documenting the criteria does not mean that an indirect preference towards the criterion does not exist. 
A marking system (Table 5) was used to overcome the difficulties mentioned. A 7-level ordinal scale was used to quantify the various assessment degrees.

Table 5: Marking system used to turn qualitative assessments into semi-qualitative assessments

\begin{tabular}{lll}
\hline Mark & Meaning & \multicolumn{1}{c}{ Rule } \\
\hline $\mathrm{A}$ & Very good & $\begin{array}{l}\text { More than one positive impact } \\
\text { Problem totally solved }\end{array}$ \\
\hline $\mathrm{B}$ & Good & One positive impact \\
\hline $\mathrm{C}$ & Rather good & $\begin{array}{l}\text { No particular data, but trend rather good } \\
\text { Positive impact seems to prevail }\end{array}$ \\
\hline $\mathrm{D}$ & Neutral & No impact \\
\hline $\mathrm{E}$ & Average & $\begin{array}{l}\text { No particular data, but trend rather bad } \\
\text { Negative impact seems to prevail }\end{array}$ \\
\hline $\mathrm{F}$ & Bad & One negative impact \\
\hline $\mathrm{G}$ & Very bad & More than one negative impact \\
\hline
\end{tabular}

Turning the semi-quantitative marks into values is based on three numerical scales with variable amplitudes. The numerical marks will depend on the criterion-based scale, i.e. a scale that depends on the criterion's weight (Schärlig, 1985) (Table 6).

Table 6: Amplitude of scale vs. criterion's weight

\begin{tabular}{|l|c|c|c|}
\hline Weight of the criterion $\mathrm{pj}$ & $0,6>\mathrm{pj}>1$ & $0,3<\mathrm{pj}<0,6$ & $0<\mathrm{pj}<0,30$ \\
\hline Amplitude of the corresponding scale & $0-10$ & $2-8$ & $3-7$ \\
\hline
\end{tabular}

In the scales, adapted from Scharlig's work (Schärlig, 1985), assessment is refined by adding two additional levels (average and rather good) (Table 7). The neutral value is kept at scale centre. The other values are distributed evenly on two centre axes.

Table 7: Numerical values vs. scales

\begin{tabular}{llll}
\hline $\begin{array}{l}\text { Mark } \\
\text { 0-10 } \\
\text { scale }\end{array}$ & $\begin{array}{l}\mathbf{2 - 8} \\
\text { scale }\end{array}$ & $\begin{array}{l}\mathbf{3 - 7} \\
\text { scale }\end{array}$ \\
\hline $\mathrm{A}$ & 10 & 8 & 7 \\
\hline $\mathrm{B}$ & 8.33 & 7 & 6.33 \\
\hline $\mathrm{C}$ & 6.66 & 6 & 5.66 \\
& & & \\
\hline $\mathrm{D}$ & 5 & 5 & 5 \\
\hline $\mathrm{E}$ & 3.33 & 4 & 4.33 \\
& & & \\
\hline $\mathrm{F}$ & 1.66 & 3 & 3.66 \\
\hline $\mathrm{G}$ & 0 & 2 & 3 \\
\hline
\end{tabular}

An application example concerning the "Replacement of chromium (VI) passivation layers by chromium (III) conversion coatings" is shown in Table 8. The water criterion's weight is 0.65 . The associated scale has therefore the greatest amplitude. There is a single, positive impact for the qualitative assessment.

According to the given rule, this corresponds to mark B, i.e. value 8.33 on the $0-10$ scale. The 86 CSP practices were assessed in the same way. 
Table 8: Application example - Replacing chromium (VI) passivation layers by chromium (III) conversion coatings

\begin{tabular}{|c|c|c|c|c|c|c|}
\hline Criteria & Water & Air & Soil & Population & Customer & $\begin{array}{l}\text { Hygiene \& } \\
\text { Safety }\end{array}$ \\
\hline $\begin{array}{l}\text { Criterion } \\
\text { weight }\end{array}$ & 0.65 & 0.13 & 0.21 & 0.27 & 0.22 & 0.37 \\
\hline $\begin{array}{l}\text { Associated } \\
\text { scale }\end{array}$ & $0-10$ & $3-7$ & $3-7$ & $3-7$ & $3-7$ & $2-8$ \\
\hline $\begin{array}{l}\text { Qualitative } \\
\text { assessment }\end{array}$ & $\begin{array}{l}\text { Less toxicity } \\
\text { on } \\
\text { environment }\end{array}$ & $\begin{array}{l}\text { Reduction of } \\
\text { air pollution } \\
\text { treatment } \\
\text { requirements, } \\
\text { decreasing of } \\
\text { chromic acid } \\
\text { in workshop's } \\
\text { ambient air } \\
\text { and outdoor }\end{array}$ & $\begin{array}{l}\text { Less soil } \\
\text { contamination } \\
\text { risks by } \mathrm{Cr} \\
\text { (VI) }\end{array}$ & $\begin{array}{l}\text { Less toxicity } \\
\text { on } \\
\text { environment }\end{array}$ & $\begin{array}{l}\text { Protection } \\
\text { against } \\
\text { similar } \\
\text { corrosion; } \\
\text { greenish } \\
\text { color } \\
\text { replacing } \\
\text { unpleasant } \\
\text { yellow }\end{array}$ & $\begin{array}{c}\text { Less } \\
\text { toxicity on } \\
\text { work place; } \\
\text { less chromic } \\
\text { acid in } \\
\text { workshop's } \\
\text { ambient air; } \\
\text { very good }\end{array}$ \\
\hline $\begin{array}{l}\text { Semi- } \\
\text { qualitative } \\
\text { assessment }\end{array}$ & B & A & B & B & $\mathrm{E}$ & A \\
\hline $\begin{array}{l}\text { Quantitative } \\
\text { assessment }\end{array}$ & 8.33 & 7 & 6.33 & 6.33 & 4.33 & 8 \\
\hline
\end{tabular}

Evaluating Assessment-related Uncertainties

Importance of subjectivity (emotions) in assessment processes has been underlined by Bouyssou (Bouyssou, 1992). Subjectivity will be encountered whenever sensors and clearly defined, repeatable measuring techniques are used for the assessment. Evaluating uncertainties is crucial to do away with subjectivity when assessing CSP practices. A $26 \%$ difference was revealed by the calculation of uncertainties made on 240 assessments, randomly taken among the 1,290 (86 practices by 15 criteria) when made by two different experts. Yet the deviation between two assessments was only $3.2 \%$; the difference between the marks was often one degree on the scale (e.g. a C instead of a B). The assessment was therefore not totally different. Thus, subjectivity-related uncertainties can be considered as insignificant.

The three assessment stages - qualitative, quantitative and uncertainty - allowed drawing up a CSP practice performance matrix. Qualitative and semi-qualitative matrices make up the core of the decision-making method. The other stages are in fact a direct application of the Electre I method.

\subsection{Establishing Outranking relations}

After drawing up the performance matrix, the concordance and discordance indices were calculated. The indices were then compared to the concordance and discordance thresholds, resp. 0.8 and 0.2., to establish outranking relations between the various practices. Thresholds were chosen from the bibliography (Maystre, 1994; Schärlig, 1985). The outranking relations were established by comparing indices to thresholds. 
The robustness analysis consisted in varying the method's parameters and observing their effects on Electre I's core. The parameters were i) concordance and discordance thresholds, ii) weights and iii) scale amplitude of the criteria.

All of the CSP practices were analysed for each strategy. Various practice combinations resulting from the 6 strategies were also considered.

- The concordance and discordance thresholds were modified individually, then collectively (Fig.3). The choice of the thresholds ( $\hat{\mathrm{c}}=0.8$ and $\hat{d}=0.2)$ is justified by the results.

- Also, solution robustness was confirmed since the validity of the results ranges are very wide (Fig.4)

- Finally, the results were not significantly altered when varying the scales assigned to the criteria.

Figure 3: Varying concordance and discordance thresholds simultaneously to change core value

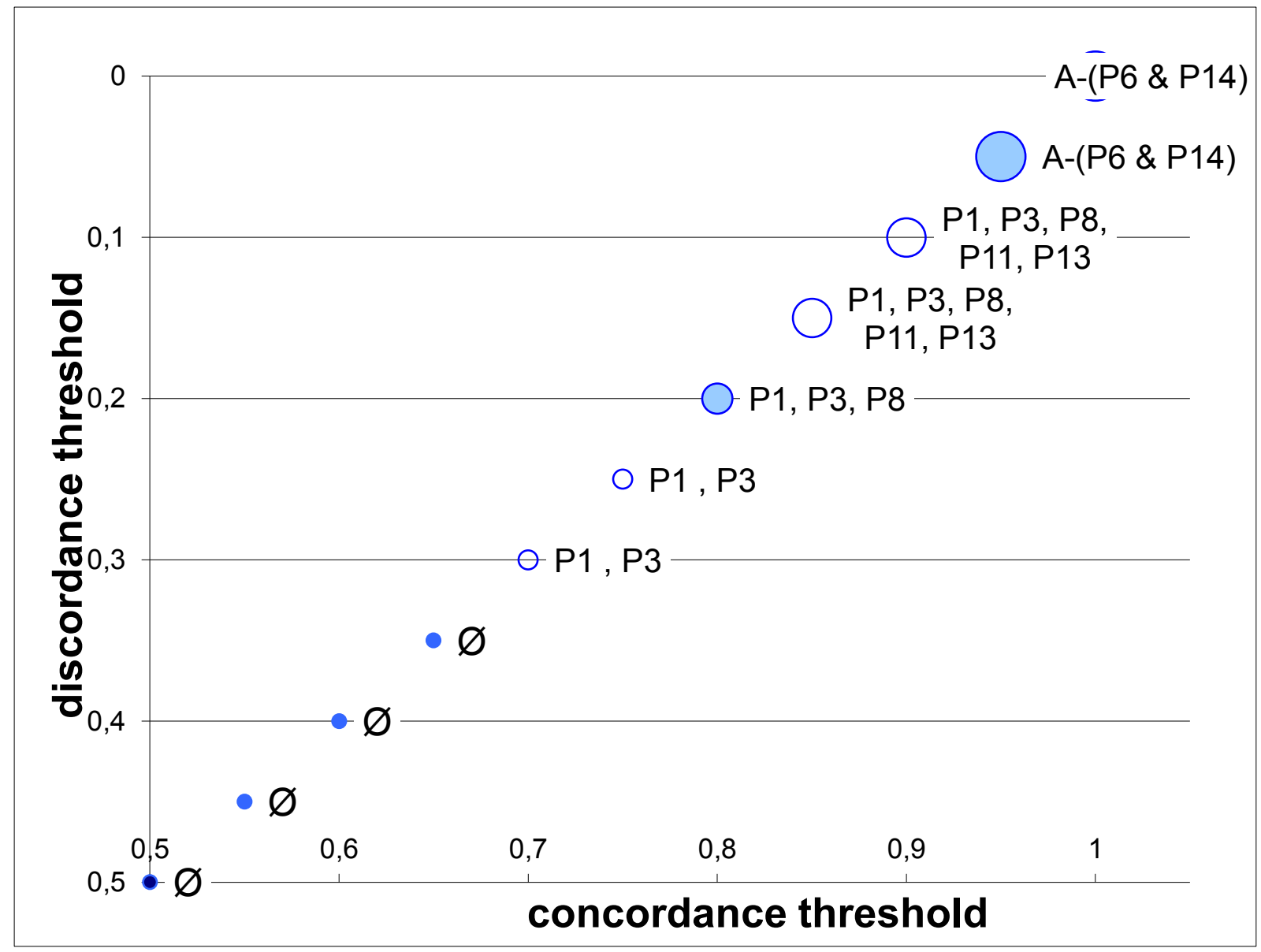


Figure 4: Core validity ranges with varying weights of criteria
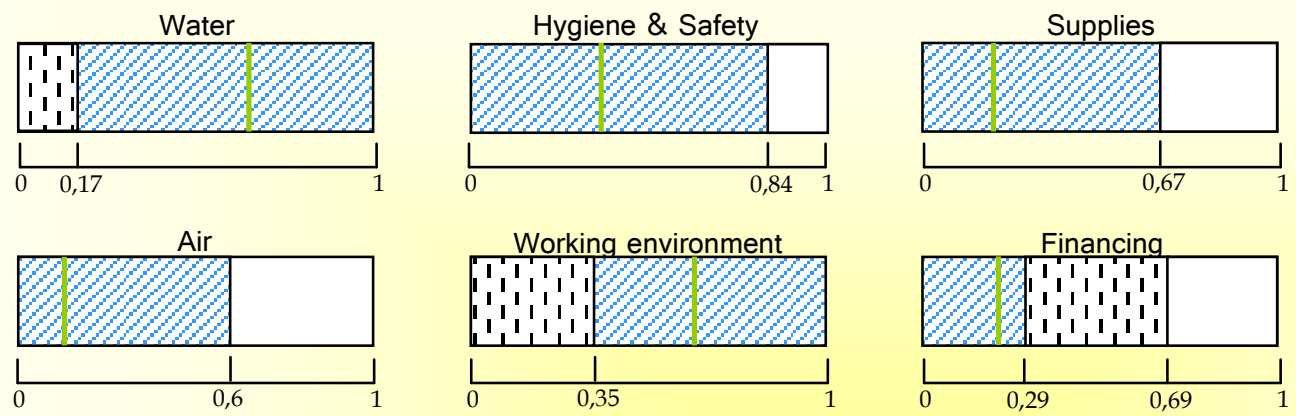

$\square \mathrm{S}_{\mathrm{n}}:\left\{\mathrm{P}_{1}-\mathrm{P}_{2}-\mathrm{P}_{2}\right\}$

Soil

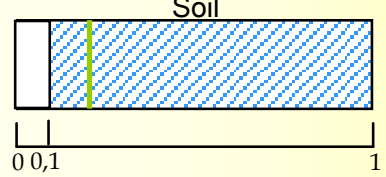

Maintenance

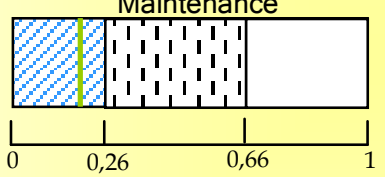

C.ıctnmer strateriv

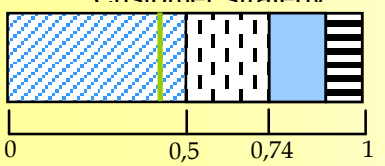

$1 S_{1}:\left\{P_{1}-P_{3}-P_{8}-P_{11}\right\}$

$\square \mathrm{S}_{2}:\left\{\mathrm{P}_{1}-\mathrm{P}_{3}\right\}$

$\square \mathrm{S}_{3}:\left\{\mathrm{P}_{1}-\mathrm{P}_{3}-\mathrm{P}_{8}-\mathrm{P}_{13}\right\}$

$\square \mathrm{S}_{4}:\left\{\mathrm{P}_{1}-\mathrm{P}_{2}-\mathrm{P}_{8}-\mathrm{P}_{11}-\mathrm{P}_{12}\right\}$

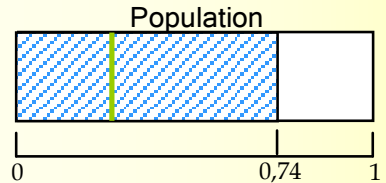

Production
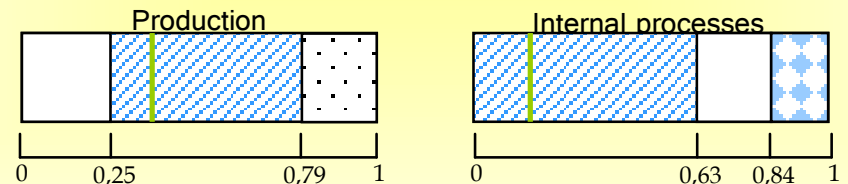

目 $\mathrm{S}_{r}:\left\{\mathrm{P}_{-}-\mathrm{P}_{2}-\mathrm{P}_{. .}-\mathrm{P}_{n}\right\}$

$\square \mathrm{S}_{6}:\left\{\mathrm{P}_{1}-\mathrm{P}_{2}-\mathrm{P}_{3}\right\}$

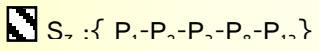

Customer
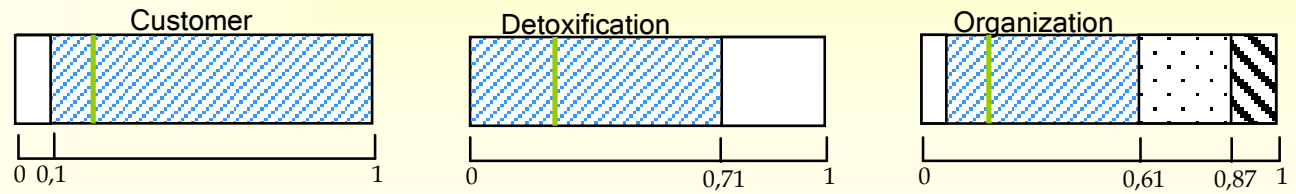

- Poids initial

The decision-making method is therefore a robust method.

\section{Results : Decision-making Tool - An Application}

\subsection{Using the Decision-making Tool}

The decision-making method helps manufacturers choose the CSP practices that best meet their needs. The CSP practice performances are compared using the 15 CSP criteria. The practice showing the best global performance for all of the criteria will be recommended to the manufacturer according to his requirements. In practical terms, a computer tool is used for implementing the method (Fig.5).

The four main stages are described in the paragraphs below. 
Figure 5: Extract of the CSP practice marking page using the decision-making tool (French version only)

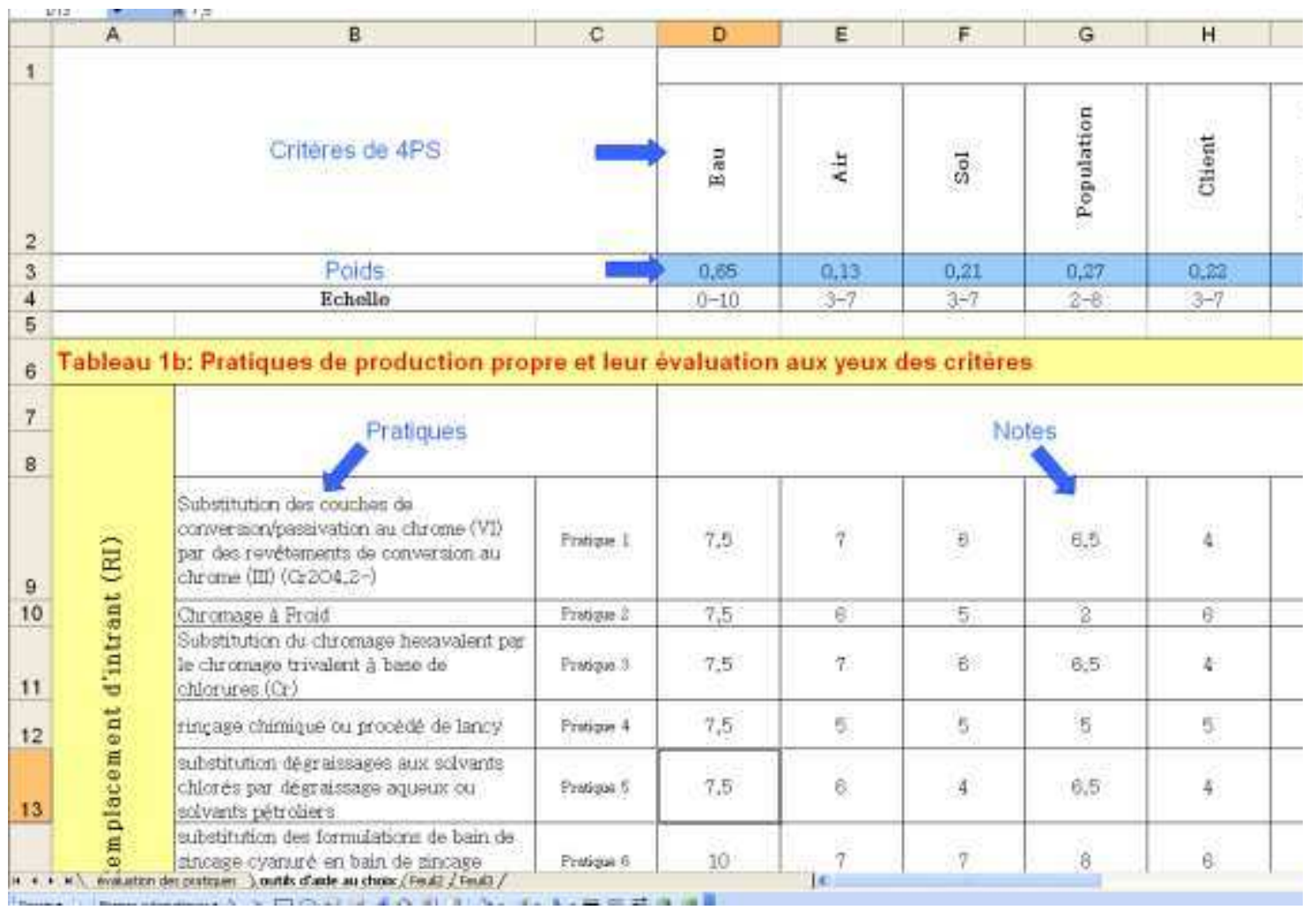

The practices to be compared among the 86 CSP practices are chosen by the user. Criteria are then assigned weights within a [0-1] range according to the user's needs. For example, if nuisance towards the population (Population criterion) is a major issue for a manufacturer who also does not want to invest too much money (Financing criterion), the heaviest weights will be assigned to these two criteria. In the same time, the requirements towards the other criteria will be decreased. As described in part 4.3, the semi-quantitative mark is turned into a value from the criterion-associated scale. The scale depends on the criterion's weight, so the quantitative value of the assessment will automatically be adjusted when modifying the criterion's weight (B on [0-10] scale $\neq \mathrm{B}$ on [3-7] scale).

The concordance and discordance thresholds will be modified by the decision-maker if he wants to tighten or loosen the outranking conditions. Thus, the so-called "outranking" practices, which prove to be the best for a majority of criteria, are chosen by the decision-making tool. In the previous example, the practices show a positive effect on nuisances while being inexpensive. Outranking is shown by a cross in a table (Fig.6). Here, Practices P2, P4 and P5 are outranked by Practice P3.

Figure 6: Establishing outranking relations

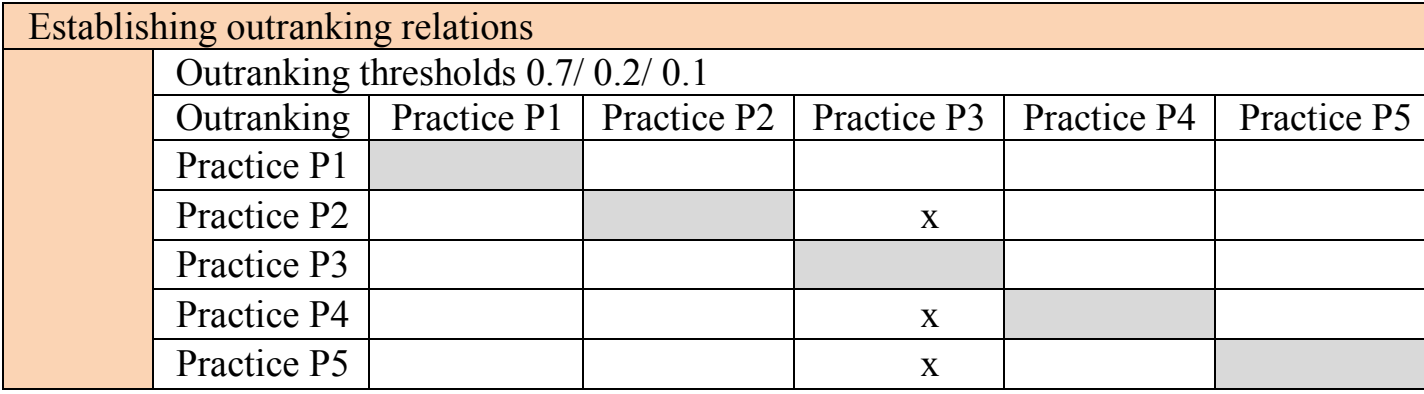


In order to fine-tune the choice between two or three practices, qualitative assessment can be carried out by the decision-maker, in order to assess the real impacts of the practices he intends to put to work. Such an action is not allowed by mark assignment-based quantitative assessment. For example, a manufacturer has the choice between two practices, i.e. "hard chromium plating" and replacement of $\mathrm{Cr}(\mathrm{VI})$ by $\mathrm{Cr}(\mathrm{III})$ ", which are outranking practices, but cannot be compared to each other. Comparing the qualitative assessments of both practices in Table 9 will help to decide that in terms of safety, reducing the amount of chromium acid in ambient air will have a more significant impact than reducing evaporation. $\mathrm{Cr}(\mathrm{VI})$ plating will then be used.

Table 9: Qualitative assessments of two comparable practices

\begin{tabular}{|c|c|c|c|c|c|c|c|}
\hline Practice & Description & Water & Air & Soil & Population & Customer & Safety \\
\hline $\begin{array}{l}\text { Replacement } \\
\text { of Cr (VI) } \\
\text { by chloride- } \\
\text { based Cr } \\
\text { (III) }\end{array}$ & $\begin{array}{l}\mathrm{Cr}(\mathrm{VI}) \text { is the } \\
\text { most widely } \\
\text { used metal, but } \\
\text { worries } \\
\text { concerning } \\
\text { toxicity and } \\
\text { excessive use } \\
\text { are growing. } \\
\text { Cr(III) is the } \\
\text { most widely } \\
\text { used alternative }\end{array}$ & $\begin{array}{l}\text { Less toxicity } \\
\text { on } \\
\text { environment }\end{array}$ & $\begin{array}{l}\text { Reduction of } \\
\text { air pollution } \\
\text { treatment } \\
\text { requirements }\end{array}$ & $\begin{array}{l}\text { Less soil } \\
\text { contamination } \\
\text { risks by } \\
\mathrm{Cr}(\mathrm{VI})\end{array}$ & $\begin{array}{l}\text { Less toxicity } \\
\text { on } \\
\text { environment, } \\
\text { Positive } \\
\text { image of } \\
\text { company }\end{array}$ & $\begin{array}{l}\text { Degraded } \\
\text { corrosion } \\
\text { resistance, } \\
\text { customer } \\
\text { may not be } \\
\text { satisfied by } \\
\text { part color }\end{array}$ & $\begin{array}{l}\text { Less } \\
\text { toxicity on } \\
\text { work place; } \\
\text { Diminution } \\
\text { of chromic } \\
\text { acid in } \\
\text { workshop's } \\
\text { ambient air }\end{array}$ \\
\hline $\begin{array}{l}\text { Hard } \\
\text { chromium } \\
\text { plating }\end{array}$ & $\begin{array}{l}\text { The bath } \\
\text { treatment temp. } \\
(\mathrm{CrVI}) \text { is kept } \\
\text { at } 18{ }^{\circ} \mathrm{C} \text { by a } \\
\text { cooling system. } \\
\text { Bath } \\
\text { concentration } \\
\text { reduced by } \\
50 \% \text {. }\end{array}$ & $\begin{array}{l}\text { Reduction of } \\
\text { water } \\
\text { consumption }\end{array}$ & $\begin{array}{l}\text { Reduction of } \\
\text { solution } \\
\text { evaporation }\end{array}$ & - & $\begin{array}{l}\text { Poor image of } \\
\text { Cr(VI) }\end{array}$ & $\begin{array}{l}\text { Better } \\
\text { quality, no } \\
\text { white edges }\end{array}$ & $\begin{array}{l}\text { Reduction } \\
\text { of solution } \\
\text { evaporation, } \\
\text { workers less } \\
\text { exposed, } \\
\text { but Cr(VI) } \\
\text { still used }\end{array}$ \\
\hline
\end{tabular}

\subsection{An application: Re-using effluents and reducing metal concentration in waste}

\section{$\checkmark$ Background of Study}

The CSP decision-making tool was tested in metal finishing facilities using an aqueous medium. Indeed, large quantities of harmful chemicals and water are used in this industrial sector, making it a highly polluting sector.

Company A is located near the town centre. It specializes in the metal finishing of decorative parts (improved corrosion resistance, electric and mechanical characteristics) in various industrial sectors, e.g. ironmongery, medical equipment, fittings, automobile and aircraft industry.

Company $\mathrm{A}$ is equipped with a wastewater treatment plant working continuously and using various waste treatment techniques (decyanation, dechromation, neutralisation, flocculation, pressure filter, chelating resins, etc.). Yet, metal concentration in waste (mainly $\mathrm{Zn}^{2+}$ and $\mathrm{Ni}^{2+}$ ) does not comply with the legislation in force. Also, the manufacturer wishes to regenerate the effluents to reduce the consumption of treatment bath water, but waste quality cannot be ensured if waste metal concentration is too high, thus preventing waste from being re-used. Indeed, pollution would be caused by the excessive content of impurities contained in the treatment baths. Therefore, the manufacturer wants to implement a technique likely to eliminate metal concentrations to comply with the legislation and reuse the treated effluents. 
Three different processes were used to eliminate the metals contained in effluents whenever the treated water was to be re-used, i.e. evaporation, ion exchange and reverse osmosis. First, CPS criteria were assigned weights by the manufacturer (Table 10). Here, the essential factors were the cost (Financing), the quality of the parts to be treated with recycled water (Customer strategy) and the conformity of the rejected water effluents (Water). Population, production and internal processes were also important parameters. A number of criteria were not taken into account by the manufacturer (Air, Soil, Customer, Detoxification, and Supplies).

Table 10: Weights assigned to criteria in the resin case study

\begin{tabular}{|c|c|c|c|c|c|c|c|c|c|c|c|c|c|c|c|}
\hline Criteria & 离 & 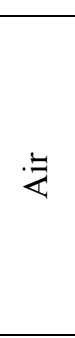 & $\overline{\overline{0}}$ & 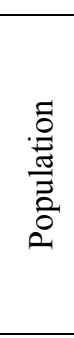 & 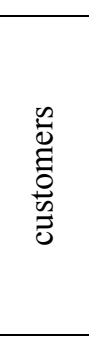 & 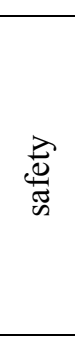 & 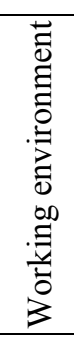 & 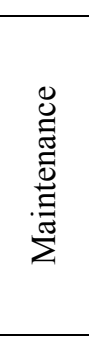 & 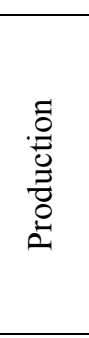 & 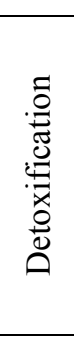 & $\begin{array}{l}\stackrel{\mathscr{v}}{\frac{2}{2}} \\
\stackrel{\vec{n}}{\vec{n}}\end{array}$ & 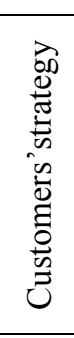 & 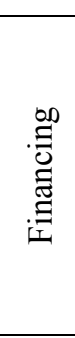 & 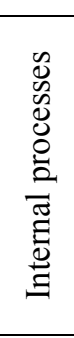 & 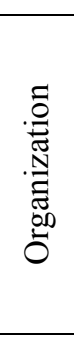 \\
\hline Weight & 1 & 0 & 0 & 1 & 0 & 0,1 & 0,2 & 0,3 & 1 & 0 & 0 & 1 & 1 & 1 & 0,5 \\
\hline Scal & $0-10$ & $3-7$ & $3-7$ & $\begin{array}{l}0- \\
10\end{array}$ & $3-7$ & $3-7$ & $3-7$ & $3-7$ & $0-10$ & $3-7$ & $3-7$ & $\begin{array}{l}0- \\
10\end{array}$ & $\begin{array}{l}0- \\
10\end{array}$ & $0-10$ & $2-8$ \\
\hline P1 : Evapo & 10,00 & 3,66 & 5,00 & 1,66 & 7,00 & 3,66 & 5,00 & 6,33 & 6,66 & 4,33 & 4,33 & 8,33 & 0,00 & 5,00 & 4,00 \\
\hline $\begin{array}{l}\text { P2 : Ion exchange } \\
\text { resins }\end{array}$ & 10,00 & 5,00 & 5,00 & 5,00 & 5,00 & 5,00 & 5,00 & 5,66 & 10,00 & 4,33 & 3,66 & 8,33 & 3,30 & 5,00 & 5,00 \\
\hline $\begin{array}{l}\text { P3 : Reverse } \\
\text { osmoses }\end{array}$ & $\underline{8,33}$ & 5,00 & 5,00 & 5,00 & $\underline{6,33}$ & 4,33 & 5,00 & 6,33 & 10,00 & 5,66 & 6,33 & $\underline{\mathbf{5 , 0 0}}$ & 8,33 & 6,66 & 7,00 \\
\hline
\end{tabular}

The outranking thresholds are 0.8 and 0.2 for concordance and discordance respectively. The outranking graph obtained is shown in Fig.7

Figure 7: Outranking graph (resins)

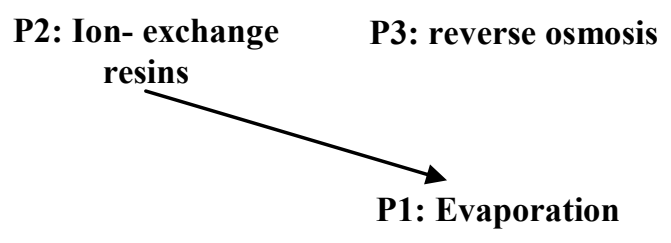

Practice P1 (evaporation) was outranked by Practice P2 (ion exchanging resins); table 10 shows that $\mathrm{P} 2$ is greater than P1for most CSP criteria. Concordance is then verified: Practice P1 was greater than P2 only when Customer, Maintenance and Supplies criteria were taken into account (italic). Now the difference between the assessments was too small to reverse outranking, therefore confirming P2 over P1. On the other hand, P3 (reverse osmosis) could not be compared to the other two practices. Table 9 shows that P3 assessments are better than P1 assessments for most criteria, especially for those whose weight is null. P1 assessments are better than P3 assessments when three criteria are considered (Customer, Water, and Customer Strategy). The Water and Customer Strategy criteria show a very high weight. Therefore, the concordance condition cannot be established easily as the concordance index is equal to the sum of the weights of the criteria for which the outranking relation has been verified, divided by the total weight sum. It also appears that the assessments show quite a big difference between one another; the non-discordance condition is thus not observed (the discordance 
index being the largest difference ratio between the assessments and this maximum scale of the criterion).

The decision-making tool concluded that these two practices could not be compared. As we ever said, sometimes, Electre can not compare actions (they are not outranked by other actions, but outrank no other actions). In our case, the two thresholds of concordance and discordance index were fixed after a sensitivity analysis (see 3.5) and seemed optimal - so the situation doesn't happen too frequently.

The graph shows that one of the practices can be eliminated from the choice. However, a feasibility study must be conducted when coming to choose between P2 and P3: in the end, Company A decided to use the ion exchanging resin process.

\section{Discussion and Conclusion}

Implementing cleaner and safer production practices within a company can be impeded both by the number of practices available and the difficulty to assess their global impact. Although manufacturers are compelled to set up preventive measures and clean technologies by French and European laws, no means are clearly available to choose the most adapted practices in one particular field.

This research work helps to choose CSP practices based on the Electre I multi-criteria analysis method. 86 CSP practices were first chosen and were assessed using 15 CSP criteria. A qualitative assessment was turned into a quantitative assessment in the form of marks. The calculation of the assessment uncertainties allowed avoiding the subjectivity factor inherent in qualitative assessments. Finally, the robustness of the method was tested successfully by varying the initial values of the parameters (thresholds, weights, scales).

The CSP method uses a computer-assisted decision-making tool. This tool enables the practices the most adapted to a particular company to be chosen by comparing performances towards the various CSP criteria. This method was drawn up and validated in the metal finishing sector.

This methodology informs decision makers by comparing up to 16 practices simultaneously. It constitutes a real decision-making aid firstly by clarifying the needs of the industrialists in attributing weights to criteria and, secondly, by identifying the most accurate practices. Nevertheless, the results must be completed with a technical feasibility study. One weakness of this method is the significance of the performance gains. Indeed, the method helps to describe the potential impacts, but does not offer a quantitative assessment of them. For example, if a practice has a good performance for the criterion "water", it creates the question of the performance percentage where there is a real gain for the industrialist. Then, this methodology could be enhanced by validating the value of each indicator for each cleaner production strategy by a larger panel of experts. Moreover, it could be interesting to work on an integrated quantitative environmental impact assessment (local and global impacts) to take into account the effect on the ecosystem and human body of each solution. Methodologies like LCA could be used.

The methodology is relatively generic. The transposition to another activity sector is then feasible. Nevertheless, indicators and cleaner practices have to be adapted to the new sector studied. For example, the textile sector could be chosen because of its similarities to metal finishing industries (size of the enterprises, production means, aqueous pollution generated, etc.). European textile BREF could be used to determine indicators and select cleaner production strategies, as it was done for the metal finishing application.

This methodology has been developed to support decision makers in their choice by having a first selection of processes hierarchically ranked following the 15 criteria presented. The CSP decisionmaking tool will of course never replace managers or experts: it will rather make their choice easier according to the weight given to the various criteria. A technical and economical feasibility study must be performed to make sure the CSP method is consistent with the strategy and means of the company.

\section{Appendix 1: Questionnaire for interview support}


1.1. According to you, compared to the overall operations of a company, what is the importance of each function versus other functions? For example, how important do you rate the function of "supply" versus "production"?

\begin{tabular}{|c|c|c|c|c|}
\hline OPERATIONS & Supply & Production & maintenance & Detoxification \\
\hline Supply & 1 & & & \\
\hline Production & & 1 & & \\
\hline maintenance & & 1 & \\
\hline Detoxification & & & & \\
\hline
\end{tabular}

1.2. Do you think that one of the following four strategies available to the company is more decisive than another one for the development of its business?

\begin{tabular}{|c|c|c|c|c|}
\hline SRATEGIES & Financial & Organisation & Internal process & Customer satisfaction \\
\hline Financial & 1 & & & \\
\hline Organisation & & 1 & & \\
\hline Internal process & -2 & & 1 & \\
\hline Customer satisfaction & & & & 1 \\
\hline
\end{tabular}

1.3. Do you think that, for the operators "Security" is more or less important that "work environment"?

\begin{tabular}{|c|c|c|}
\hline OPERATORS & Work environment & Security \\
\hline Work environment & 1 & \\
\hline Security & 1 & 1 \\
\hline & & \\
\hline
\end{tabular}

1.4. For Metal Finishing sector, which impacts affect the most the ecosystem?

\begin{tabular}{|c|c|c|c|}
\hline ECOSYSTEM & Water & Air & Soil \\
\hline Water & 1 & & \\
\hline Air & & 1 & \\
\hline Soil & & & 1 \\
\hline
\end{tabular}

1.5. How do you rank the items below in their contribution to the proper functioning of the company?

\begin{tabular}{|c|c|c|c|}
\hline COMPAGNY & Strategy & Operators & Operations \\
\hline Strategy & 1 & & \\
\hline Operators & & 1 & \\
\hline Operations & & & \\
\hline
\end{tabular}

1.6. The environment of a company has several components. What priority would you give to each component as far as impacts of the company on the environment are concerned?

\begin{tabular}{|c|c|c|c|}
\hline ENVIRONMENT & Economic & Ecosystem & Social \\
\hline Economic & 1 & & \\
\hline Ecosystem & 20 & 1 & \\
\hline Social & & & 1 \\
\hline
\end{tabular}

2. Scales for indicators

The goal is to build scales for each indicator

2.1. To assess presenteeism (average proportion of time spent by employees per month) : does the following scale seems to you adequate?

$>96 \%$ : very good

$85 \%$ to $96 \%$ : good

$<85 \%$ : Poor

$\square$ Yes

$\square$ No, otherwise give a scale that seems most suitable 
2.2. To assess the customer satisfaction, does the following scale seem to you adequate?

$<1 \%$ of claims: very satisfied

$<5 \%$ of claims: relatively satisfied

$<10 \%$ claim: neither satisfied nor dissatisfied

$>10 \%$ of claims: relatively dissatisfied

$>50 \%$ of claims: very dissatisfied

$\square$ Yes

$\square$ No, otherwise give a scale that seems most suitable

2.3. For the turnover of equipment (the share of annual incomes reinvested in new equipment), does the following scale seems to you adequate?

$<5 \%$ of annual incomes reinvested: low

$5 \%$ to $10 \%$ of annual incomes reinvested: good

$>10 \%$ of annual incomes reinvested: strong

$\square$ Yes

$\square$ No, otherwise give a scale that seems most suitable

\section{Acknowledgments:}

We would like to thank the cluster of environment of the Rhone-Alps Region for the funding given for this research. We would also want to thank the directors of the metal finishing industry for their trust and our solid partnership.

\section{References}

Ahlroth S., Nilsson M., Finnveden G., Hjelm O., Hochschorner E., 2001, Weighting and valuation in selected environmental systems analysis tools - suggestions for further developments, Journal of Cleaner Production, 19, $145-156$

Aissani, L., 2008. Intégration des paramètres spatio-temporels et des risques d'accident à l'analyse du cycle de vie: application à la filière hydrogène énergie et à la filière essence. Thèse sci. Saint-Etienne: ENSM-SE, 352p ; pp. 237-253. (only in French).

Barros, M. C., et al., 2007. Integrated pollution prevention and control for heavy ceramic industry in Galicia (NW Spain). Journal of Hazardous Materials 141, 680-692.

Bouyssou D., Duckstein L., Goicoechea A., Zionts S., 1992, On some properties of outranking relations based on a concordance-discordance principle, Multiple Criteria Decision Making, SpringerVerlag, Berlin, 93-106

BREF STM 2006, Integrated Pollution Prevention and Control Reference Document on Best Available Techniques for the Surface Treatment of Metals and Plastics, European Commission, August 2006, 546

CNUEDR, 1992, Conférence des Nations Unies sur l'Environnement et le Développement, Report on the conference of the United nation onThe environmental and the development. Rio de Janeiro, $3^{\text {rd }}$ to 14 th of June, 1992. Disponible oline <http://www.agora21.org/dd.html>

Dijkmans, R., 2000. Methodology for selection of best available techniques (BAT) at the sector level. Journal of Cleaner Production 8, 11-21.

Directive 2008/1/EC of the European Parliament and of the Council of 15 January 2008 concerning integrated pollution prevention and control 
Främling K., 1996. Modélisation et apprentissage des préférences par réseaux de neurones pour l'aide à la décision multicritère. $\mathrm{PhD}$ Thesis.

Gault G., 2009, Quelle perception de l'environnement chez les dirigeants de PME? - Résultats d'un nouveau sondage ADEME/TNS SOFRES; Colloque PM4E: Environnement et Maitrise de l'énergie; Paris, 17-18 mars 2009 (available in French)

Geldermann, J. and Rentz, O., 2004. The reference installation approach for the techno-economic assessment of emission abatement options and the determination of BAT according to the IPPC-directive. Journal of Cleaner Production 12, 389-402.

Giannetti B. F., Bonilla S. H., Silva I. R. and Almeida C. M. V. B., 2008, Cleaner production practices in a medium size gold-plated jewellery company in Brazil: when little changes make the difference. Journal of Cleaner Production. 16, 1106-1117

Kabongo J., 2004 ; Intégrer économie et écologie: le cas de l'industrie canadienne. Vertigo. 5, 1-12

Kjaerheim G., 2003, Cleaner production and sustainability. Journal of Cleaner Production. 13, 329339.

Krippendorff K (2004) Content Analysis - an introduction to its methodology (2nd edition) London, Sage Publications.

ISO 14040 : 2006, Standard. Environmental management - life cycle assessment - principles and framework. Paris : AFNOR, 23p.

Kaplan R. et Norton D. P.; Linking the Balanced ScoreCard to strategy; California management review; volume 39; Issue 1; p 53-79; 1996

Laforest V., Debray B., Grange D., Bourgois J., 1998, "A computer tool for the management of wastewater in metal finishing facilities", Short paper à la 2ème Conférence Internationale "Advanced Wastewater treatment, recycling and reuse", Milan Italie, 14-16 septembre 1998,1115-1118

Laforest V., 2008, Applying Best Available Technologies in environmental management accounting? From the definition to an assessment methodology..., 5th EMAN book "Environmental Management Accounting for Cleaner Production", EMAN, Springer, ISBN: 978-1-4020-8912-1, 500p pp29 à 48

Lanteigne R.,Laforest V., 2007, Specifications for an Internet Based Clean Technology Information Support System for SMEs, Journal of Cleaner Production, Vol 15, 409-416.

Maystre L. Y., Pictet J. and Simos J., 1994, Méthodes multicritères Electre: Description, conseils pratiques et cas d'application à la gestion environnementale. Presses polytechniques et universitaires romandes, Lausanne.

Polders C., Van den Abeele L., Derden A., Huybrechts D., 2012, Methodology for determining emission levels associated with the best available techniques for industrial waste water, Journal of Cleaner Production, Volumes 29-30, , Pages 113-121

Raymond G., Piatyszek E., Laforest V., 2008, Reducing the environmental impact in the metal finishing industry by employing cleaner and safer production strategies. Second International conference on Environmental Economics and investment assessment. Cadiz. 28 -30 mai 2008.

Roy B., 1991, The outranking approach and the foundations of ELECTRE methods Theory and Decision, 31, 49-73 
Saaty T. L., 1984, Decision making for leaders. Les Editions ESF, Paris

Schärlig A., 1985, Décider sur plusieurs critères, panorama de l'aide à la décision multicritère. Presses polytechniques et universitaires romandes, Lausanne.

Styles David, O’Brien Phillip, O’Boyle Shane, Cunningham Peter, Donlon Brian, B. Jones Michael, 2009 , Measuring the environmental performance of IPPC industry: I. Devising a quantitative science-based and policyweighted Environmental Emissions Index, environmental science and policy, 12, 226-242

Valderrama C., Granados R., Cortina JL, Gasol C. M., Guillem M., Josa Al., 2012, Implementation of best available techniques in cement manufacturing: a life-cycle assessment study, Journal of Cleaner Production 25 60-67

UNEP, United Nation for the Environmental Program; Cleaner production; online www.unep.fr/pc/cp/understanding_cp/home.htm 